\title{
"Una strada fatta sopra dell'acqua": genesi e rappresentazione di alcuni ponti palladiani
}

\author{
Alberto Sdegno \\ Veronica Riavis
}

\section{Abstract}

II saggio affronta il tema del disegno e la ricostruzione digitale di alcuni ponti di Andrea Palladio, sottolineando l'efficacia costruttiva e i riferimenti morfologici principali.

È singolare che più che considerarli degli strumenti tecnici per connettere due rive, l'autore li consideri "strade sopra dell'acqua", o, nel caso delle soluzioni più significative, delle vere e proprie piazze urbane, luoghi di ritrovo stanziale con una propria dignità architettonica.

Obiettivo della ricerca è ricostruirne la genesi geometrica e la configurazione spaziale, in modo da rilevarne le caratteristiche specifiche e tecniche. Le opere analizzate sono le due soluzioni per l'area realtina a Venezia e il ponte di Cesare sul Reno, quest'ultimo ricostruito anche considerando l'interpretazione che è stata fatta da Massimo Scolari per la sua installazione presso il Centro Internazionale di Studi di Architettura Andrea Palladio di Vicenza.

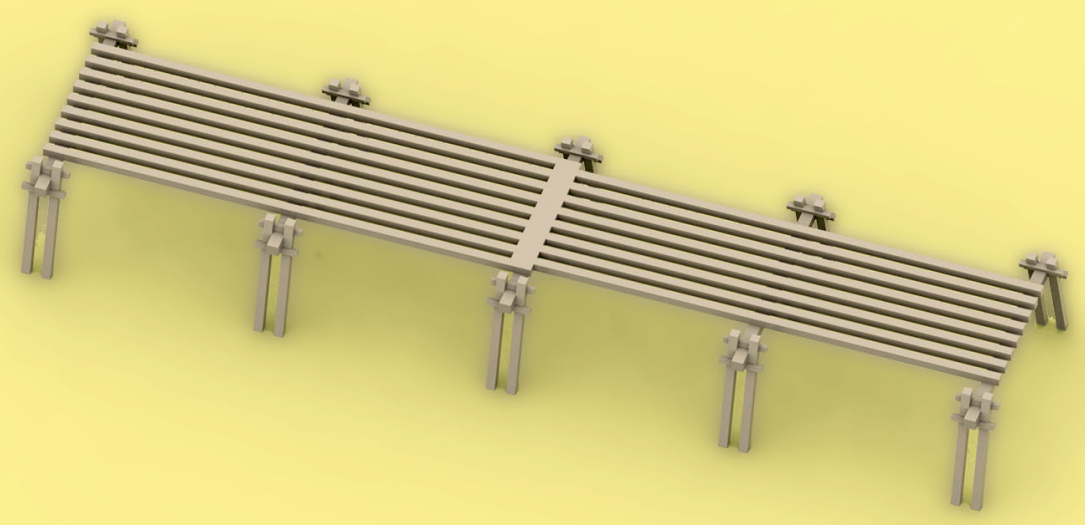




\section{Introduzione}

Tra le opere che Andrea Palladio descrive nel suo trattato I Quattro Libri dell'Architettura [Palladio 1570], i ponti costituiscono un interessante caso di studio, al quale l'autore dedica una buona parte del terzo libro. Singolare è innanzitutto che nelle prime stesure del volume [Zorzi 1958, pp. I45-193] essi non siano contemplati, mentre nella stesura finale - pubblicata a Venezia nel 1570 - saranno presentati in venti pagine, circa la metà dell'estensione del terzo libro. Per introdurre l'argomento l'architetto inizia a trattare il tema delle strade e di come "per farle che fossero commode, e brevi, forarono i monti, seccarono ile paludi, e congionsero con ponti" [Palladio I 570, III, p. 5]. Come spesso ci ha abituato, però, Palladio esonda nella trattazione dalle premesse iniziali e propone soluzioni che non soltanto risolvono problemi tecnici di connessione e attraversamento di sponde, ma che diventano dei veri e propri spazi della città, elementi architettonici di grande efficacia formale e rappresentatività scenica.

Non descriveremo tutte le opere presenti nella sezione, ma ci soffermeremo ad analizzare i casi più significativi, che denotano la grande destrezza e abilità dell'autore non solo nella narrazione di opere costruite, ma - come ha già fatto nel libro secondo dedicato alle case private - anche nella descrizione di proprie soluzioni, quali ad esempio il caso emblematico del ponte di Rialto.

\section{Il ponte "nel mezo d'una città"}

Tra i ponti di pietra "di mia inventione" Palladio pone la sua soluzione per il ponte di Rialto. Per la verità non verranno esplicitati nel testo i riferimenti all'area per la quale è previsto, limitandosi a queste parole in premessa: "Bellissima à mio giudicio è la inventione del Ponte, che segue; e molto accomodata al luogo, ove si doveva edificare: ch'era nel mezo d'una città, la quale è delle maggiori, e delle più nobili d'Italia" [Palladio I570, III, p. 25]. I riferimenti, quindi, restano sottintesi: non soltanto la zona di Rialto non è citata, ma nemmeno il nome di Venezia; l'autore aggiunge soltanto che "il Ponte veniva à esser nel luogo apponto, ove si riducono i mercanti à trattare i loro negocii" e per tale motivo "io vi ordinava delle botteghe" [Palladio I570, III, p. 25]. Palladio pertanto cerca di risolvere l'esigenza funzionale

Fig. I. Andrea Palladio, prospetto di ponte (identificato con la prima versione del ponte di Rialto), c.a I553-54 (Museo Civico di Vicenza, foglio D25r).

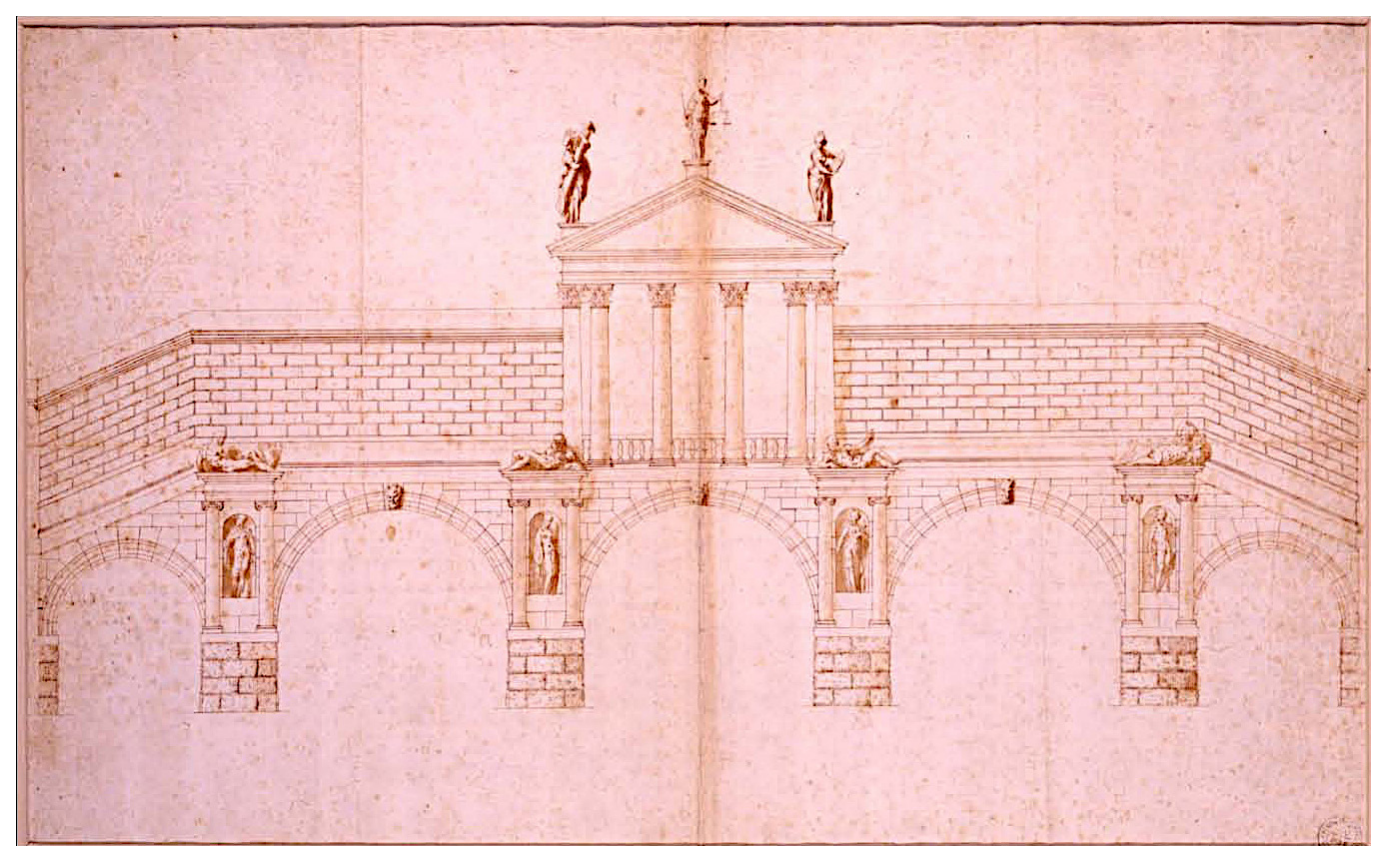



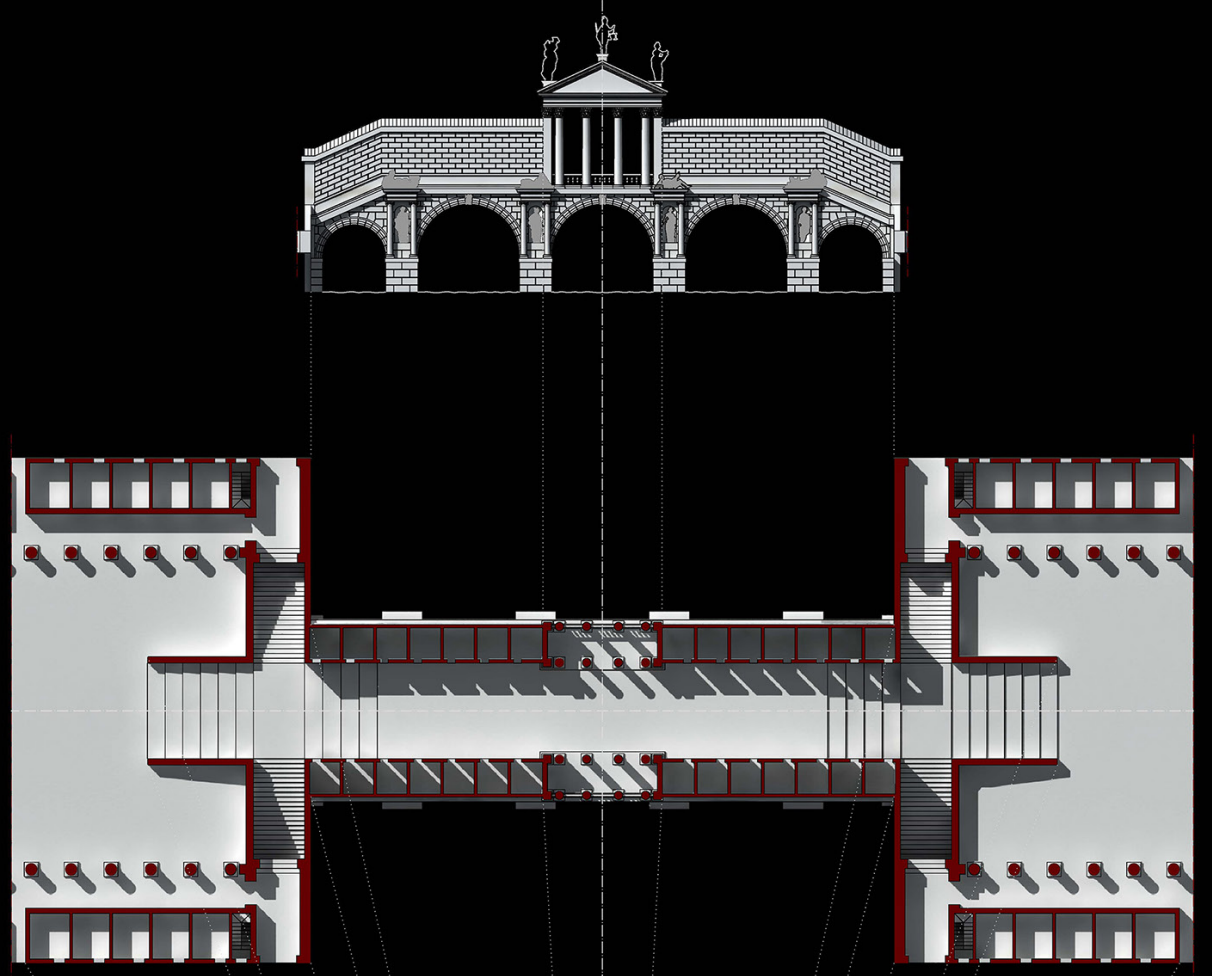

${ }_{0}=-C=-C=0$
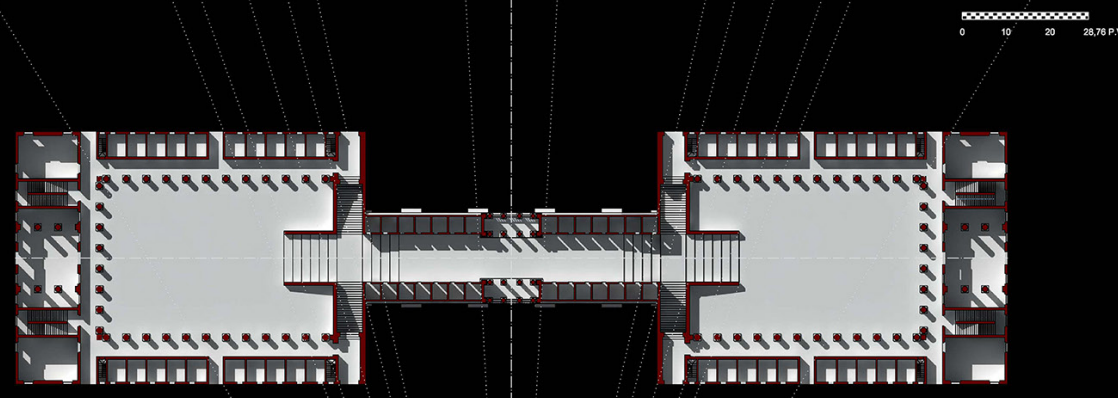

Fig. 2. Ricostruzione digitale della prima version del ponte di Palladio per Rialto (elaborazione grafica P. Ravagnan).

$0=-0-0-0$

$0 \begin{array}{lll}0 & 20 & 28,76 \mathrm{P}\end{array}$ 
Fig. 3. Andrea Palladio, pianta e prospetto di ponte (identificato con seconda versione del ponte di Rialto) [Palladio I 570, libro III, p. 26].

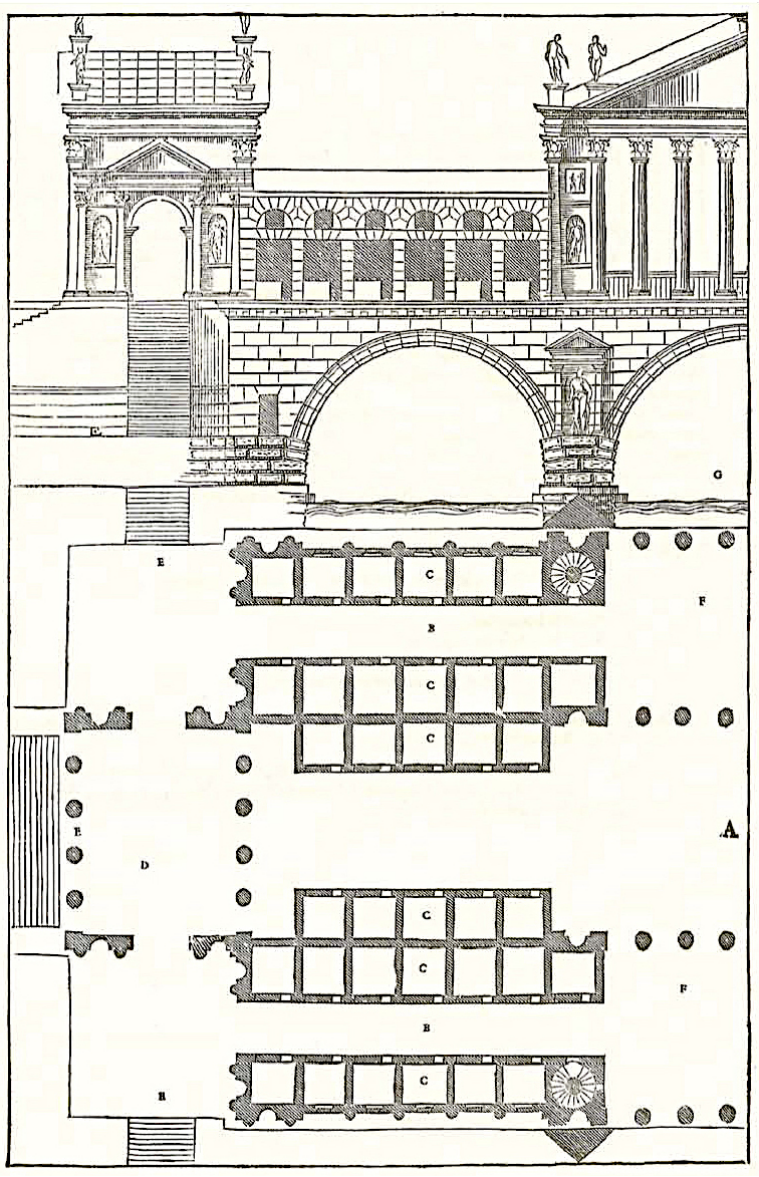

specifica del contesto con una soluzione architettonica adeguata, progettando di fatto "tre strade: quella di mezo ampia, e bella; e l'altre due, ch'erano una per banda; alqualto minori" [Palladio I570, III, p. 25]. Una vera e propria piazza cittadina, quindi, avente una configurazione pianeggiante, dal momento che era anticipata - nelle due estremità - da due rampe di scala che permettono a chi attraversava di sostare in maniera comoda al suo interno. Aggiunge l'autore che in realtà la sua "inventione" deriva da suggerimenti romani, poiché, come scrive, "il Ponte Elio in Roma [...] era anticamente ancor egli coperto tutto di loggie" [Palladio I 570, III, p. 25].

Come hanno descritto anche Donatella Calabi e Paolo Morachiello la vicenda del ponte di Rialto è abbastanza complessa [Calabi, Morachiello 1987]. Si trattava infatti di sostituire il ponte di legno più volte soggetto a rifacimenti - che si vede ancora nella volumetria di Jacopo de' Barbari del I 500 - con una struttura in pietra. Già nel I 554 i provveditori al ponte richiedono proposte e progetti alternativi, ma solo nel I569 il Senato veneziano vuole effettivamente costruire un ponte per quell'area. Le due ipotesi progettuali per Rialto, simili ma al contempo molto diverse, possono essere considerate tra le più interessanti soluzioni di ponti in pietra di Palladio. Entrambe le versioni rispecchiano l'idea principale di un ponte polifunzionale con botteghe che abbiamo sopra descritto, situato nella zona centrale del mercato di Venezia.

Tra i caratteri ricorrenti nelle due versioni per il ponte veneziano vi sono l'impiego sistematico di archi con valenza strutturale, gli ordini architettonici ed il timpano centrale che conferiva una gerarchia all'intero complesso.

La prima soluzione per Rialto (ca. I553- 1554), (fig. I ) è rintracciabile in un documento conservato presso la il Museo Civico diVicenza. I disegni mostrano sul recto il prospetto parziale del ponte a cinque arcate e sul verso il suo sviluppo planimetrico, di notevole interesse in 
Fig. 4. Ricostruzione digitale della seconda versione del ponte di Palladio per Rialto (elaborazione grafica P. Ravagnan).

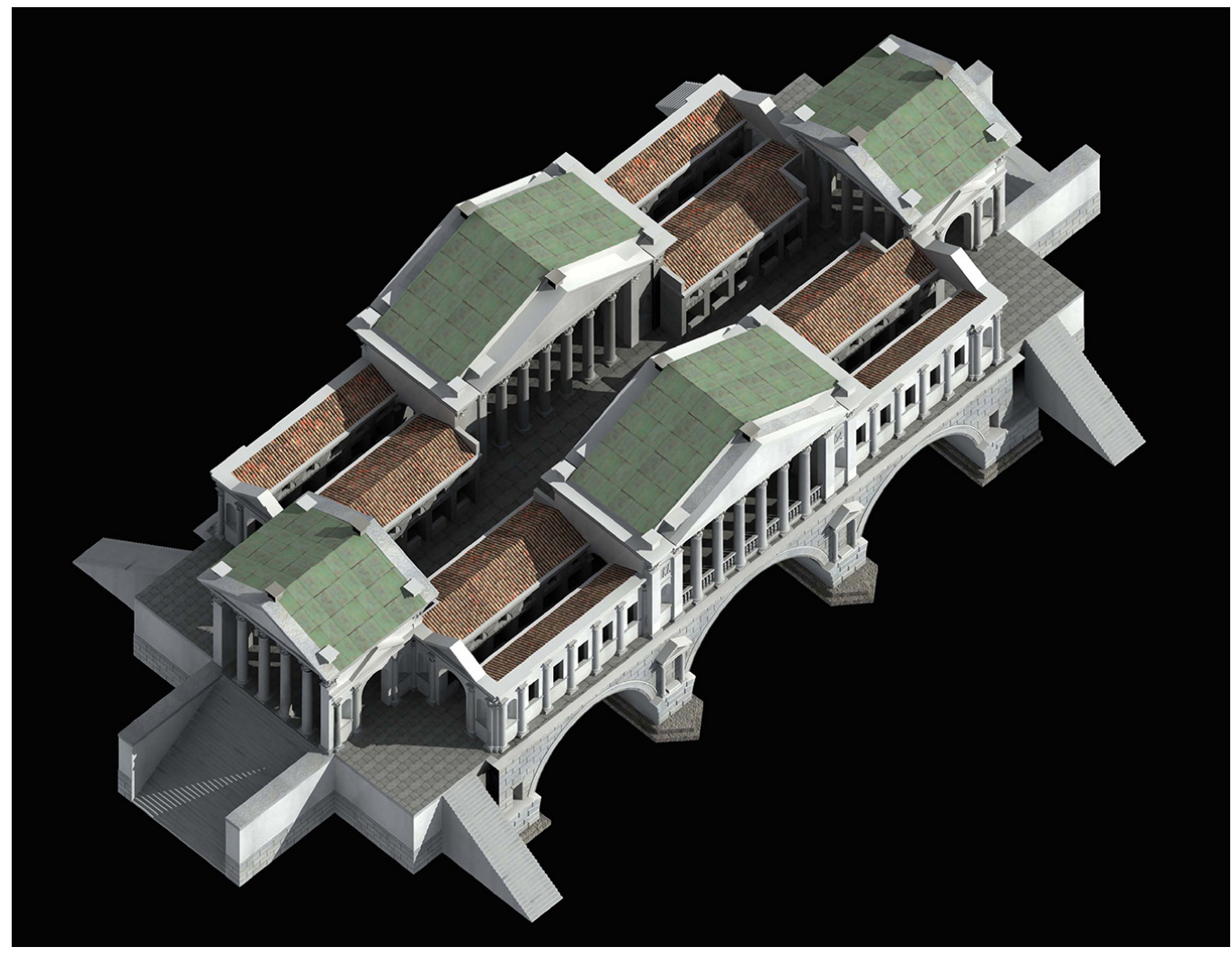

quanto una delle poche testimonianze di progetto palladiano a scala urbana a noi pervenute [Beltramini 2008]. La struttura è dimensionabile grazie alla specifica metrica indicata nel disegno: il ponte è lungo 132 piedi $(45,89 \mathrm{~m})$, mentre i due campi alla fine del ponte misurano $32 \times 26$ 'pasa' (pasa sta per gradino, I,78 m, ovvero 5 piedi vicentini), che corrispondono a 57,20 m di lunghezza e 46,47 m di larghezza.

Degli interni non vi sono informazioni, ma si possono identificare due serie di sette negozi disposti su due lati ed alcune scale.

La modellazione della prima versione del ponte palladiano (fig. 2) e della decorazione dei suoi apparati è stata avviata secondo i materiali grafici a disposizione. Lo studio è stato applicato anche per la localizzazione del sito, tracciando i lati del fiume e l'acqua.

II secondo progetto per il Ponte di Rialto (fig. 3), più noto del primo, è stato pubblicato da Palladio nei Quattro Libri. Partendo dalla grafica palladiana, numerosi ridisegni sono stati realizzati nel corso del XVIII secolo, tra i quali quelli di Francesco Muttoni e Ottavio Bertotti Scamozzi. Di particolare rilievo per lo sviluppo di questa ricerca è stato il saggio di Antonio Rondelet [Rondelet I84I]: l'autore, cercando di comprendere meglio la storia del ponte palladiano, ne ha studiato struttura e fattibilità di realizzazione fornendo preziose considerazioni e dettagli.
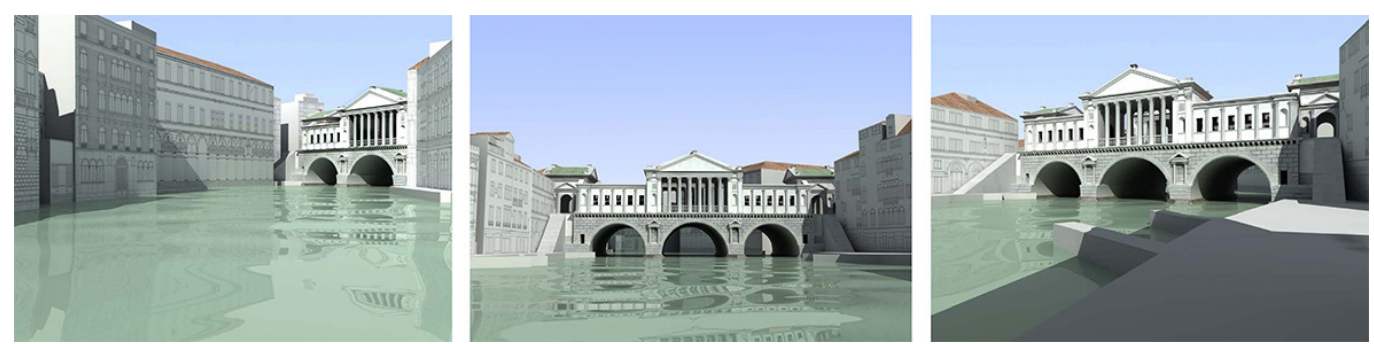

Fig. 5. Fotogrammi della video animazione digitale della seconda versione del ponte di l'inserimento nel contesto (elaborazione grafica P. Ravagnan). 
Oltre a questi approfondimenti, la determinazione digitale del ponte (fig. 4) si è basata sui disegni del trattato (planimetria, prospetto longitudinale e sezione dell'opera), che hanno costituito una sufficiente descrizione delle parti principali poi ricostruite tridimensionalmente. Una animazione digitale ha permesso di verificare l'impatto effettivo che avrebbe avuto quest'opera se fosse stata realizzata, adottando un particolare stratagemma figurativo: alla verosimiglianza del ponte non realizzato ha fatto da contraltare la virtualità dei prospetti reali del contesto veneziano, applicati come tessiture grafiche sui volumi degli edifici, ricostruiti digitalmente, che si affacciano su Canal Grande (fig. 5). Un sottile esercizio comunicativo per mettere in relazione realtà e virtualità nella loro mutua corrispondenza.

Fig. 6. Andrea Palladio, Ponte di Cesare sul Reno 570, libro II p. 14]

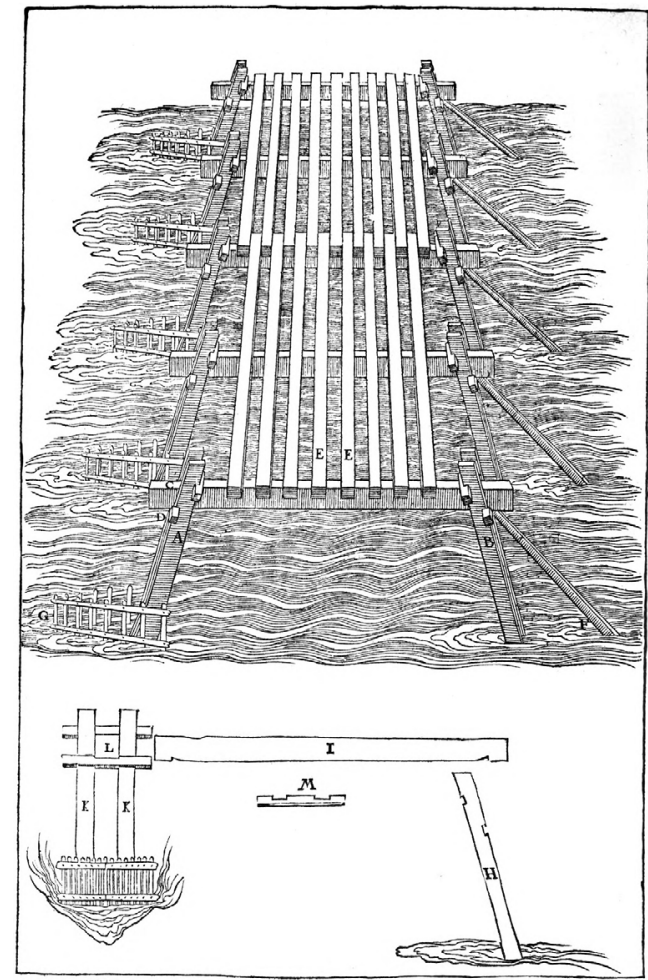

\section{II ponte di Cesare sul Reno}

Tra i ponti del passato che più incuriosirono l'architetto vicentino vi è il Ponte sul Reno che Caio Giulio Cesare fece costruire sul Reno nel 55 a.C. in un delicato momento della guerra di Gallia. Connettere le due sponde attraverso una struttura temporanea avrebbe consentito, oltre al superamento fisico del fiume che divideva i due territori dei Galli e dei Germani, anche di acquisire quella fama, stima e notorietà, che sarebbero durate nel tempo. Costruito in soli dieci giorni e realizzato interamente in legno su telai disposti di profilo rispetto alla corrente del fiume, il ponte rispondeva ai requisiti specifici di rapidità di montaggio (grazie alla programmazione del processo costruttivo, nonché alla serialità e prefabbricazione degli elementi) e di resistenza strutturale per l'ingegnosità dei collegamenti che impiegavano i particolari fermagli (detti fibulae), oltre a quelli vitruviani di firmitas, utilitas, e venustas. Composto da moduli disposti in successione, il ponte poteva essere "infinitamente" lungo, salvo la difficoltà di dover inserire pali di sostengo in fiumi di eccessiva profondità. La proposta di Cesare, descritta nel De Bello Gallico, lascia ampi margini di dubbio sulla tecnica impiegata, tanto che diverse sono state le ipotesi avanzate nel corso degli anni, tra le quali quella di Fra Giocondo, Leon Battista Alberti, Jean Borrel e Andrea Palladio. Proprio la 


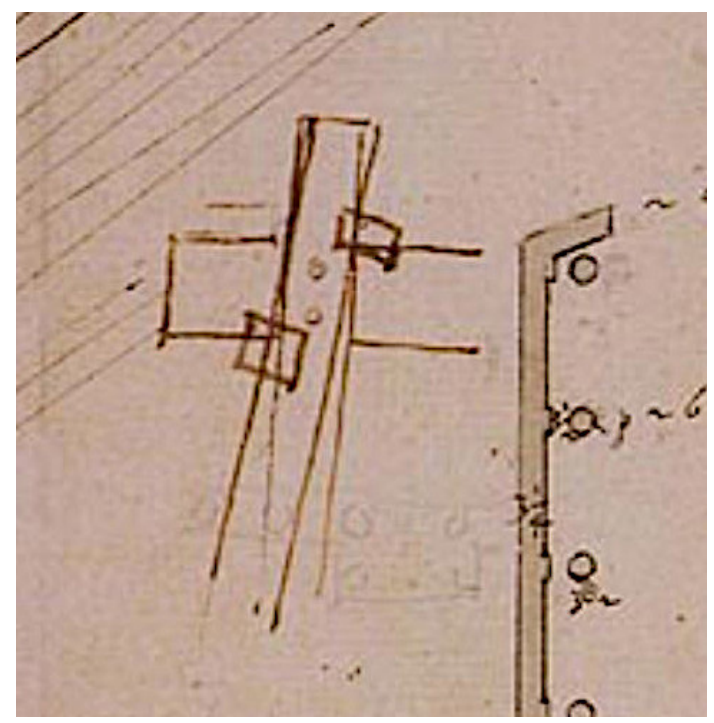

soluzione palladiana sembra essere la più convincente, perché riesce a risolvere il sistema d'incastro a 'fibula' - solo accennato da Cesare nel suo testo ma non descritto - evitando l'uso di chiodi.

La ricerca ha previsto la costruzione digitale del ponte di Cesare sulla base dell'interpretazione di Palladio, la prototipazione fisica per la verifica tecnica e la simulazione dinamica dell'impatto dell'acqua sul ponte con le tecniche di realtà virtuale immersiva.

La ricostruzione del ponte di Cesare sul Reno, secondo l'ipotesi palladiana, è stata condotta attraverso il confronto e l'analisi delle seguenti fonti: la tavola a pagina I4 del III libro de I Quattro Libri dell'Architettura (fig. 6); lo schizzo del funzionamento delle fibule conservato presso l'archivio RIBA di Londra (Vol. XI, Fol. I9r) [I] (fig. 7); la tavola XIV dell'edizione de I Commentari di C. Giulio Cesare [Caesar 1575] [2]. A questi sono stati aggiunti alcuni studi condotti di recente [Scolari 2002; Beltramini 2002].

L'architetto vicentino riporta nel trattato quanto descritto nel testo di Cesare adottando come unità di misura il piede romano antico [3] $(29,62 \mathrm{~cm})$ dimensionando precisamente la trave trasversale [4], il pilone inclinato e la distanza tra due piloni inclinati [5]. Dai disegni palladiani è possibile invece dedurre l'inclinazione tra trave trasversale e piloni [6], la lunghezza e la sezione della fibula e la posizione dei denti d'intaglio su trave e piloni. I denti di incastro superiori e inferiori sono mostrati reciprocamente nello schizzo del RIBA e nella tavola dei Quattro Libri.

L'interasse dei cavalletti non è specificato in alcun modo da Palladio, ma è riconducibile effettuando una restituzione geometrica sulle travi trasversali e travetti rappresentati nella vista prospettica d'insieme (fig. 8). La restituzione prospettica, infatti ha consentito di determinare, oltre alla dimensione dei singoli travetti dell'orditura superiore, anche l'interasse delle travi trasversali (circa 40 piedi) e di conseguenza la lunghezza complessiva della porzione di ponte rappresentata (4 campate, circa 160 piedi). L'altezza totale del ponte non è invece deducibile dalla tavola dei Quattro Libri, se non per la lunghezza dei piloni inclinati rappresentati al di sopra del livello dell'acqua (circa 16 piedi e mezzo).

Desunte tali informazioni grafico-dimensionali, la ricerca ha proseguito con la determinazione tridimensionale degli elementi - geometricamente semplificati secondo il disegno palladiano - che compongono il ponte verificando sia in fase di modellazione che di prototipazione i principi geometrico-strutturali della soluzione e della riproducibilità in continua crescita di questa architettura di collegamento (figg. 9, I0). Tale procedimento ha confermato quindi come il ricorso alla modularità e alla prefabbricazione permetta un'agevole e rapida costruzione, così come le operazioni di smontaggio e di sostituzione di pezzi per eventuali necessità. 
Fig. 8. Restituzione prospettica del disegno di Palladio relativo pretive di Cesare sul Reno (elaborazione grafica elaborazione grafic . Riavis)
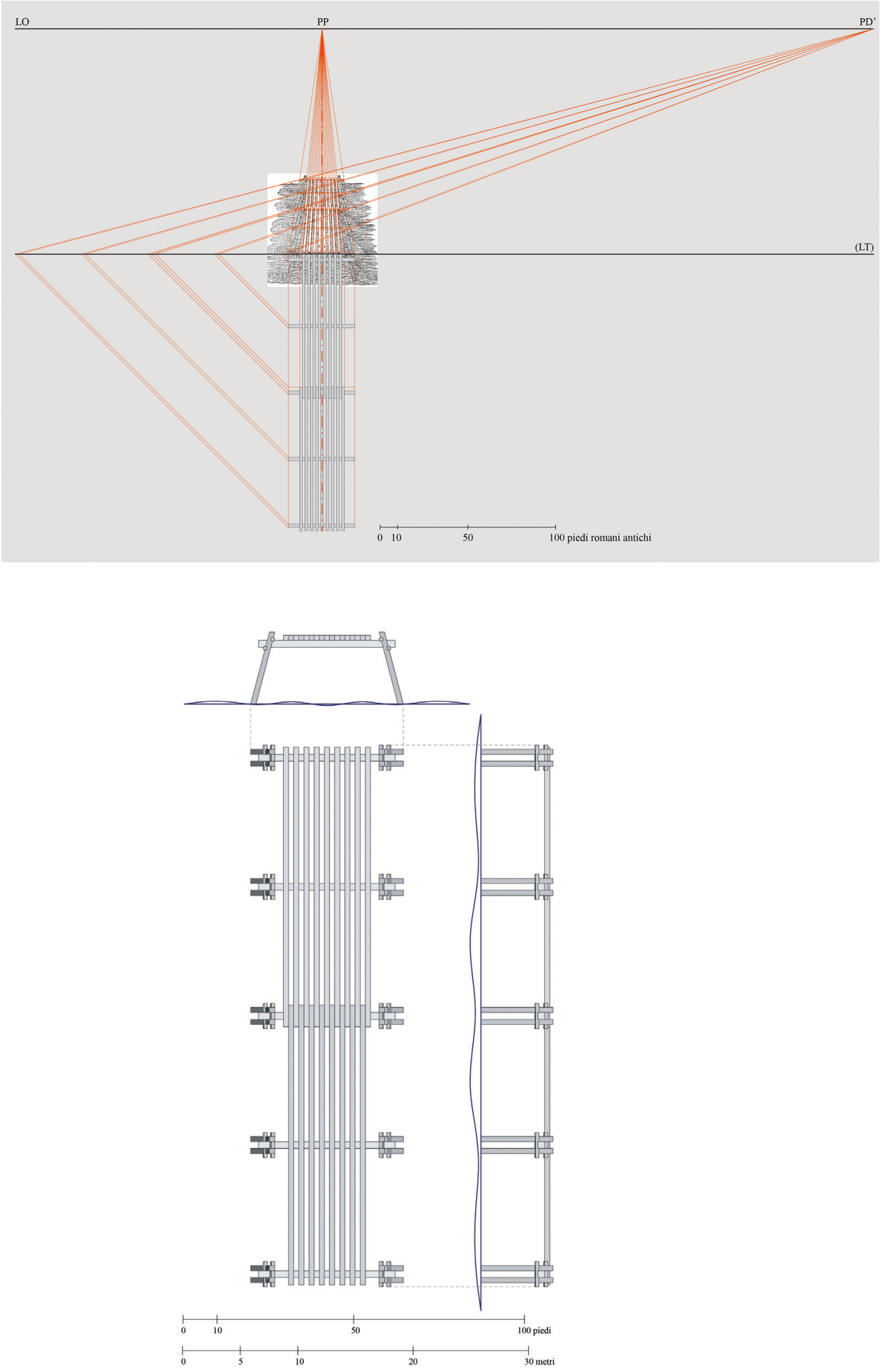
Fig. 10. Assonometria del modello digitale del progetto di Palladio per il Ponte di Cesare sul Reno (elaborazione grafica V. Riavis)
Fig. I I. Massimo Scolari, Schizzo dell'installazione per il ponte di Cesare su Reno secondo Palladio Reno secondo Palladio
presso Palazzo Barbaran presso Palazzo Barbaran
da Porto a Vicenza, 2002

Fig. 12. Installazione di Massimo Scolari per il ponte di Cesare sul Reno secondo Palladio presso Palazzo Barbaran da Porto a Vicenza, 2002 (fotografia di Pino Guidolotti).

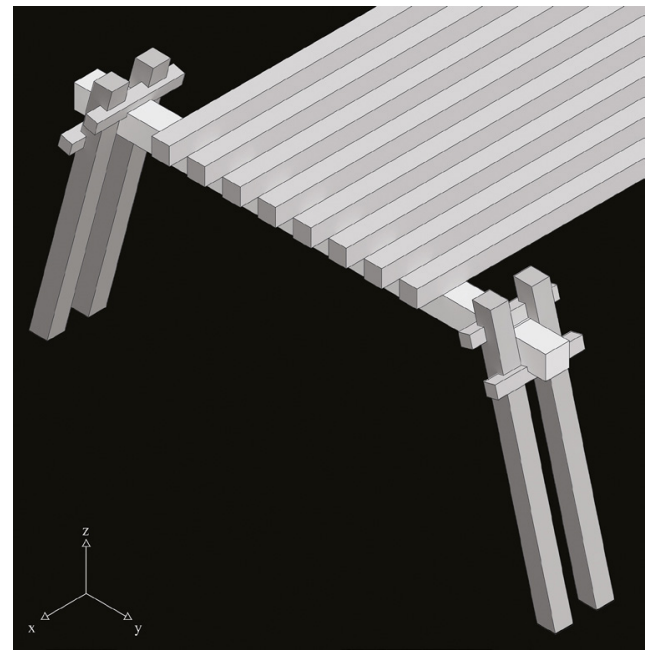

Una ricostruzione del sistema di aggancio della trave con il palo è stata fatta da Massimo Scolari nel 2002 (figg. I I, I2) in occasione della mostra John Soane e i ponti in legno svizzeri. Architettura e cultura tecnica da Palladio ai Grubenmann tenutasi presso Palazzo Barbaran da Porto a Vicenza, sede del Centro Internazionale di Architettura Andrea Palladio. In questa occasione è stato possibile osservare in dettaglio la soluzione palladiana, con il sistema di fibulae che permettevano di reggere l'incastro tra elemento strutturale verticale e trave orizzontale, anche grazie al fatto che Scolari ha deciso di raddoppiare la scala degli elementi, trasformando questo accorgimento tecnico in una vera e propria scultura architettonica di grande impatto percettivo e restituendo così quell'impressione di grandiosità ben presente in alcune opere di scrittori antichi. Non a caso è proprio Massimo Scolari a ricordarci che "per quest'opera, tanto grandiosa quanto effimera, potrebbero valere le parole che Plutarco scrisse a proposito delle opere militari di Demetrio: "le loro grandi proporzioni atterrivano anche i suoi amici, la loro bellezza dilettava anche i nemici' (Plutarco, Vita di Demetrio, 18)" [Scolari 2002, pp. 4, 5].
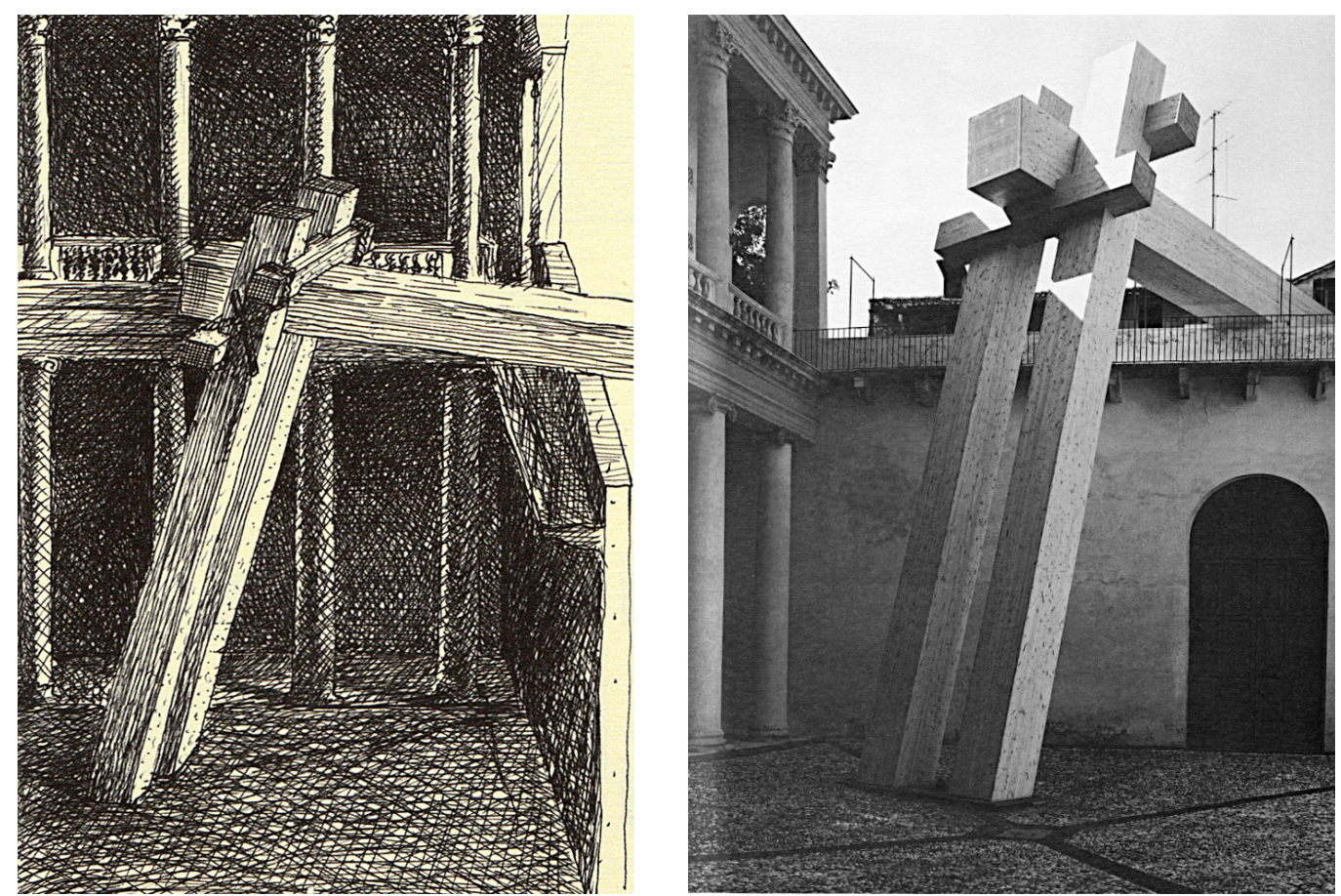


\section{Conclusioni}

La tematica relativa alla concezione e costruzione di ponti è tra le più interessanti sotto molteplici aspetti, tra i quali quelli politico-sociali e tecnici. I ponti, infatti, ricoprono un rilevante ruolo nel tentativo di dominare la natura e superare i suoi ostacoli, dando la possibilità di acquisire anche militarmente un certo territorio, o di effettuarvi scambi commerciali e culturali.

Le considerevoli difficoltà tecniche connesse alla loro progettazione e all'esecuzione riguardano prevalentemente le dinamiche di cantiere, le caratteristiche e il movimento dei carichi, così come la difesa dai corsi d'acqua [piene ed esondazioni] e la manutenzione.

In base alle informazioni grafiche e documentali disponibili sia nei Quattro Libri, così come i disegni autografi di Palladio e studi successivi condotti da diversi autori sull'architetto vicentino, la ricerca qui presentata è stata completata dando forma digitale ai ponti analizzati - i due progetti per Rialto, e l'interpretazione del Ponte di Cesare sul Reno.

Le diverse versioni di ponti sono state affrontate mediante la modellazione solida e NURBS per la ricostruzione tridimensionale degli elementi compositivi di diversa complessità geometrica.

Tutti i modelli digitali sono stati ottimizzati e finalizzati alla comprensione della ricostruzione geometrica e funzionale degli stessi, sia sotto forma di simulazione dinamica (animazione video e immersiva) che fisica mediante le tecniche di prototipazione rapida. In tal modo è stato possibile non solo apprezzare la ricchezza del dettaglio architettonico palladiano, ma di verificarne anche il funzionamento delle componenti connettive che costituiscono i ponti da lui concepiti e analizzati.

\section{Note}

[I] Si tratta di un dettaglio del funzionamento della fibula rappresentato schematicamente di fianco ai disegni del Foro di Nerva e Tempio di Minerva [Zorzi 1958, p. 74, fig. I48].

[2] La fonte testuale consiste nella traduzione del passo di Giulio Cesare e nelle didascalie all'immagine fornite a pagina I 3 dei Quattro Libri, riportate fedelmente nell'edizione dei Commentari.

[3] Si è assunto che Palladio consideri tale unità di misura in base ad alcuni riscontri effettuati da Howard Burns sui disegni delle antichità di Verona [Beltramini 2002, p. 16].

[4] Si precisa la presenza di una discontinuità per la lunghezza della trave trasversale tra quanto riportato nella didascalia (40 piedi) rispetto al disegno schematico delle tavole dei Quattro Libri e dei Commentari (lunghezza ridotta a 29 piedi).

[5] Trave trasversale $(40 \times 2 \times 2$ piedi), pilone inclinato $(1,5 \times 1,5$ piedi $\times$ lunghezza indefinita per assenza di informazioni sul letto del fiume) e distanza tra due piloni inclinati (2 piedi).

[6] Inclinazione tra trave trasversale e piloni $\left(105^{\circ}\right)$, lunghezza e sezione della fibula $(7,5 \times|\times|$ piedi).

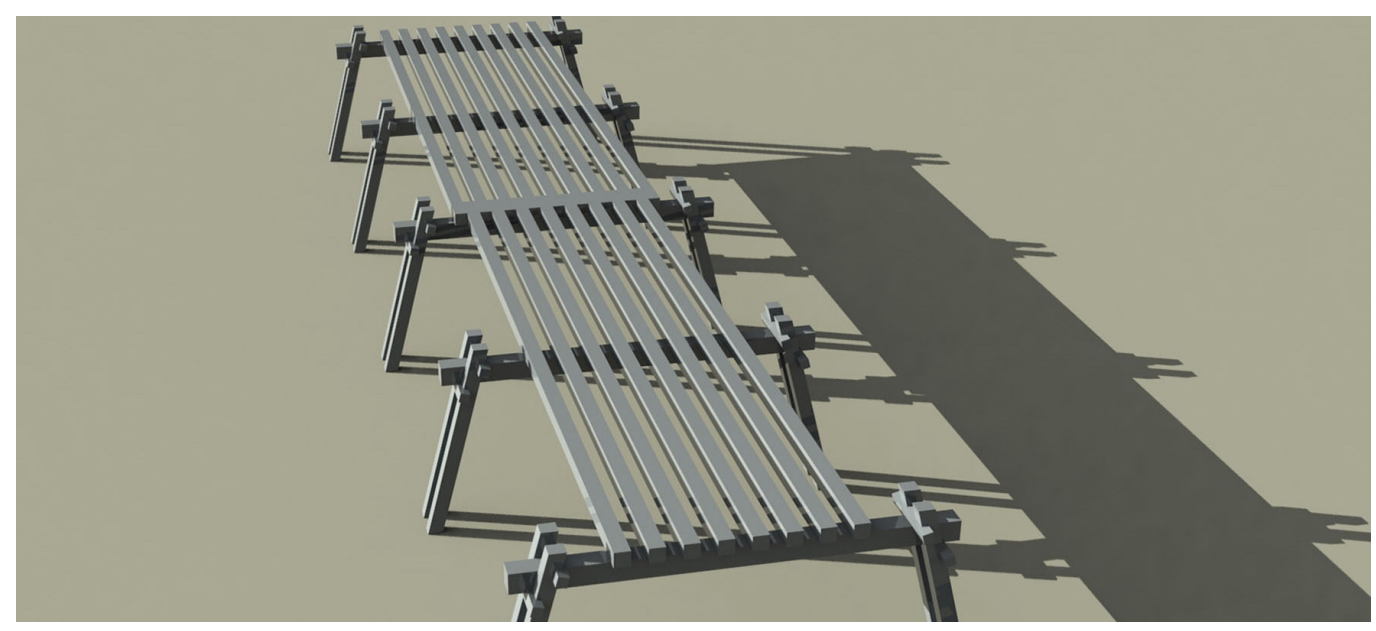




\section{Riferimenti bibliografici}

Azzi Visentini Margherita (1980). I ponti di Palladio. Milano: Electa.

Battilotti Donata (2008). Belli, forti e durevoli? I ponti di Palladio. In Barbieri Franco et al. (a cura di). Palladio I 508-I580. II simposio del cinquecentenario. Venezia: Marsilio.

Beltramini Guido (2002). Andrea Palladio e il ponte di Cesare. In Scolari Massimo. Il ponte di Cesare sul Reno secondo Palladio. In Quaderni del Museo Palladio, 4. p. 16.

Beltramini Guido (2008).Venezia: i progetti per Rialto. In Beltramini Guido, Burns Howard (a cura di). Palladio. Venezia: Marsilio pp. 184-195.

Bertotti Scamozzi Ottavio (1796). Le fabbriche e i disegni di Andrea Palladio raccolti e illustrati da Ottavio Bertotti Scamozzi. Vicenza: Giovanni Rossi.

Caesar Gaius lulius (1520). Commentaria Caesaris prius à locundo impressioni data.... Florentiae: per haeredes Philippi luntae.

Caesar Gaius lulius (I575). I Commentari di C. Giulio Cesare, con le figure in rame de gli alloggiamenti, de' fatti d'arme, delle circonuallationi delle citta, \& di molte altre cose notabili descritte in essi. Fatte da Andrea Palladio per facilitare a chi legge, la cognition dell'historia. Venezia: Pietro de Franceschi.

Calabi Donatella, Morachiello Paolo (1987). Rialto: le fabbriche e il ponte, I 5 / 4- I 59 I. Torino: Einaudi.

Gros Pierre, Beltramini Guido (2002). Il ponte di Cesare sul Reno. In Maggi Angelo, Navone Nicola (a cura di). John Soane e i ponti in legno svizzeri. Architettura e cultura tecnica da Palladio ai Grubenmann. Mendrisio: Accademia di Architettura; Vicenza: Centro Internazionale di Studi di Architettura Andrea Palladio. pp. I63- 189.

Palladio Andrea (1570). I Quattro Libri dell'architettura di Andrea Palladio. Venezia: Domenico De Franceschi.

Rondelet Antonio ( 184 I). Saggio storico sul ponte di Rialto. Mantova: Negretti.

Scolari Massimo (2002). Il ponte di Cesare sul Reno secondo Palladio. In Quaderni del Museo Palladio, 4. pp. I - 6.

Tampone Gennaro (2000). Sulle caratteristiche strutturali ed esecutive dei ponti lignei di Palladio. Firenze, Bollettino Ingegneri, 12. pp. 2-6

Tampone Gennaro, Mannucci Massimo, Macchioni Nicola (2002). Strutture di legno. Cultura, conservazione, restauro. Milano: De Lettera.

Zorzi Giangiorgio (1958). I disegni delle antichità di Andrea Palladio.Venezia: Neri Pozza Editore.

\section{Autori}

Alberto Sdegno, Università degli Studi di Udine, alberto.sdegno@uniud.it

Veronica Riavis, Università degli Studi di Udine, veronica.riavis@uniud.it

Per citare questo capitolo: Sdegno Alberto, Riavis Veronica (2020). "Una strada fatta sopra dell'acqua": genesi e rappresentazione di alcuni ponti palladiani/"A road made above water": genesis and representation of some palladian bridges. In Arena A., Arena M., Brandolino R.G., Colistra D., Ginex G., Mediati D., Nucifora S., Raffa P. (a cura di). Connettere. Un disegno per annodare e tessere. Atti del $42^{\circ}$ Convegno Internazionale de Docenti delle Discipline della Rappresentazione/Connecting. Drawing for weaving relationships. Proceedings of the 42th International Conference of Representation Disciplines Teachers. Milano: FrancoAngeli, pp. 2694-2715. 


\title{
"A Road Made Above Water": Genesis and Representation of some Palladian Bridges
}

\author{
Alberto Sdegno \\ Veronica Riavis
}

\section{Abstract}

The essay deals with the theme of drawing and the digital reconstruction of some bridges by Andrea Palladio, emphasizing the construction effectiveness and the main morphological references.

It is singular that rather than considering them as technical tools to connect two banks, the author considers them "roads above the water", or, in the case of the most significant solutions, real urban squares, permanent meeting places with their own architectural dignity.

The aim of the research is to reconstruct its geometric genesis and spatial configuration, in order to detect its specific and technical characteristics. The analyzed works are the two solutions for the Venice area and the Caesar bridge over the Rhine, the latter rebuilt also considering the interpretation that was made by Massimo Scolari for its installation at the International Center for Architecture Studies Andrea Palladio of Vicenza.

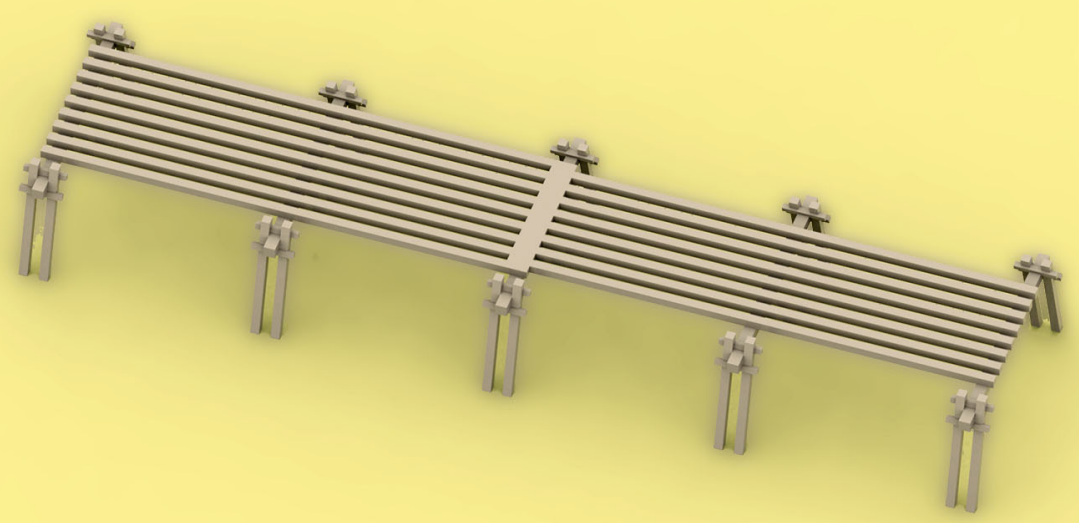




\section{Introduction}

Among the works that Andrea Palladio describes in his treatise I Quattro Libri dell'Architettura [Palladio 1570], bridges constitute an interesting case study, to which the author dedicates a good part of the third book. First of all, it is singular that in the first drafts of the volume [Zorzi 1958, pp. I45-193] they are not contemplated, while in the final draft -published in Venice in 1570- they will be presented in twenty pages, about half of the extension of the third book. To introduce the topic, the architect begins to deal with the theme of roads and how "to make them comfortable and short, they pierced the mountains, dried up the marshes, and united with bridges" [Palladio I570, III, p. 5]. As often accustomed to us, however, Palladio overflows from the initial premises in the discussion and proposes solutions that not only solve technical problems of connection and crossing of banks, but that become real spaces of the city, architectural elements of great formal effectiveness and scenographic representation.

We will not describe all the works in the section, but we focus on analyzing the most significant cases, which denote the author's great dexterity and ability not only in the narration of built works, but -as he has already done in the second book dedicated to private houses-also in the description of its solutions, such as for example the emblematic case of the Rialto bridge.

\section{The bridge "in the middle of a city"}

Among the stone bridges "of my invention" Palladio places his solution for the Rialto bridge. In truth, the references to the area of Venice will not be explicit in the text, limiting themselves to these words in the introduction: "Very beautiful to me is the invention of the Bridge, which follows; and very pleased with the place where it was to be built: it was in the middle of a city, which is one of the largest and most noble in Italy" [Palladio I570, III, p. 25]. The references, therefore, remain implied: not only the Rialto area is not mentioned, but not even the name of Venice; the author adds only that "the Bridge came to be in the place where the merchants are and to deal with their shops" and for this reason "I ordered shops there" [Palladio I570, III, p. 25]. Palladio therefore tries to solve the specific functional

Fig. I. Andrea Palladio, elevation of a bridge (identified with the first version of the Rialto bridge), c. 1553-54 (Civic Museum of Vicenza, sheet D25r).

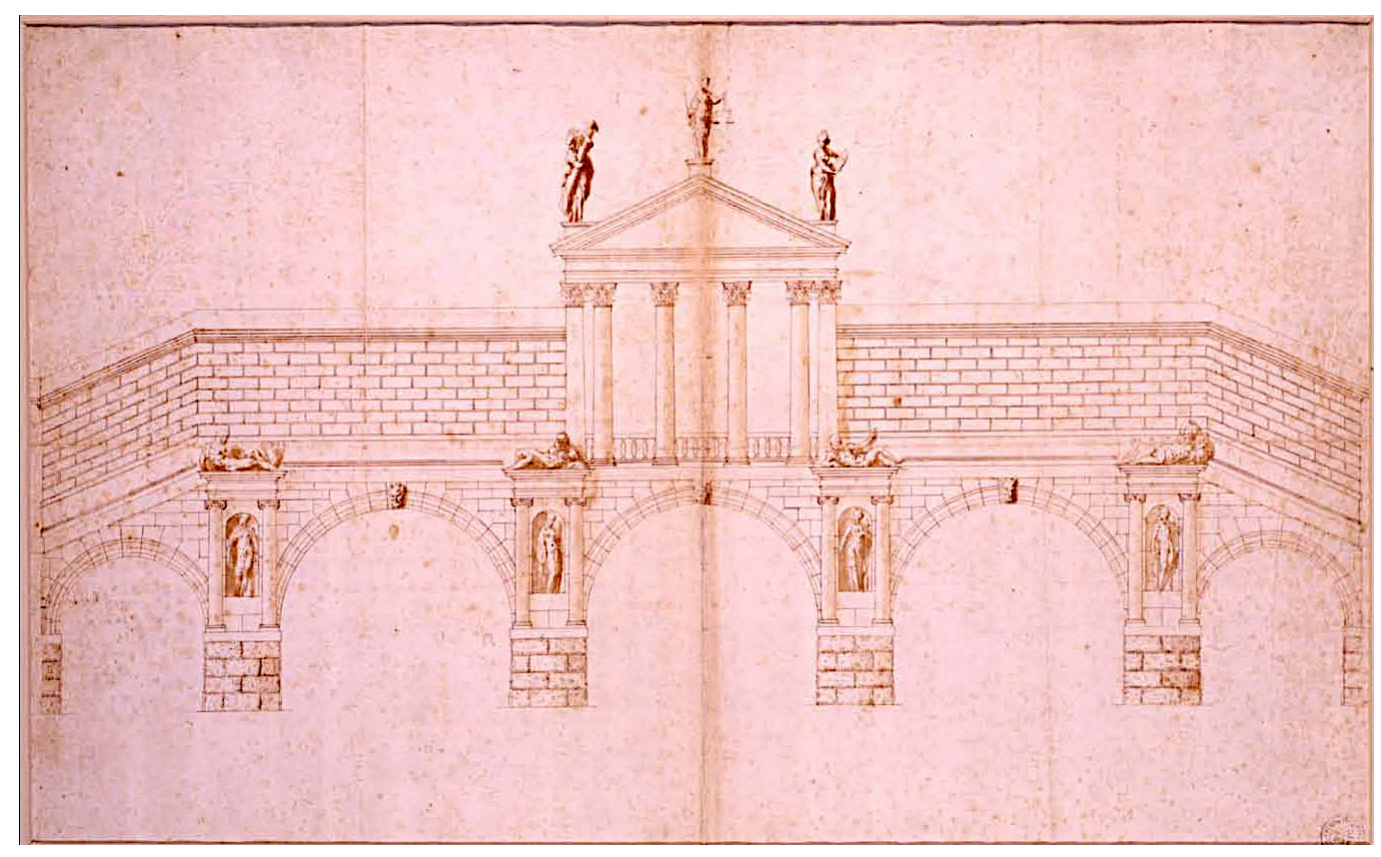



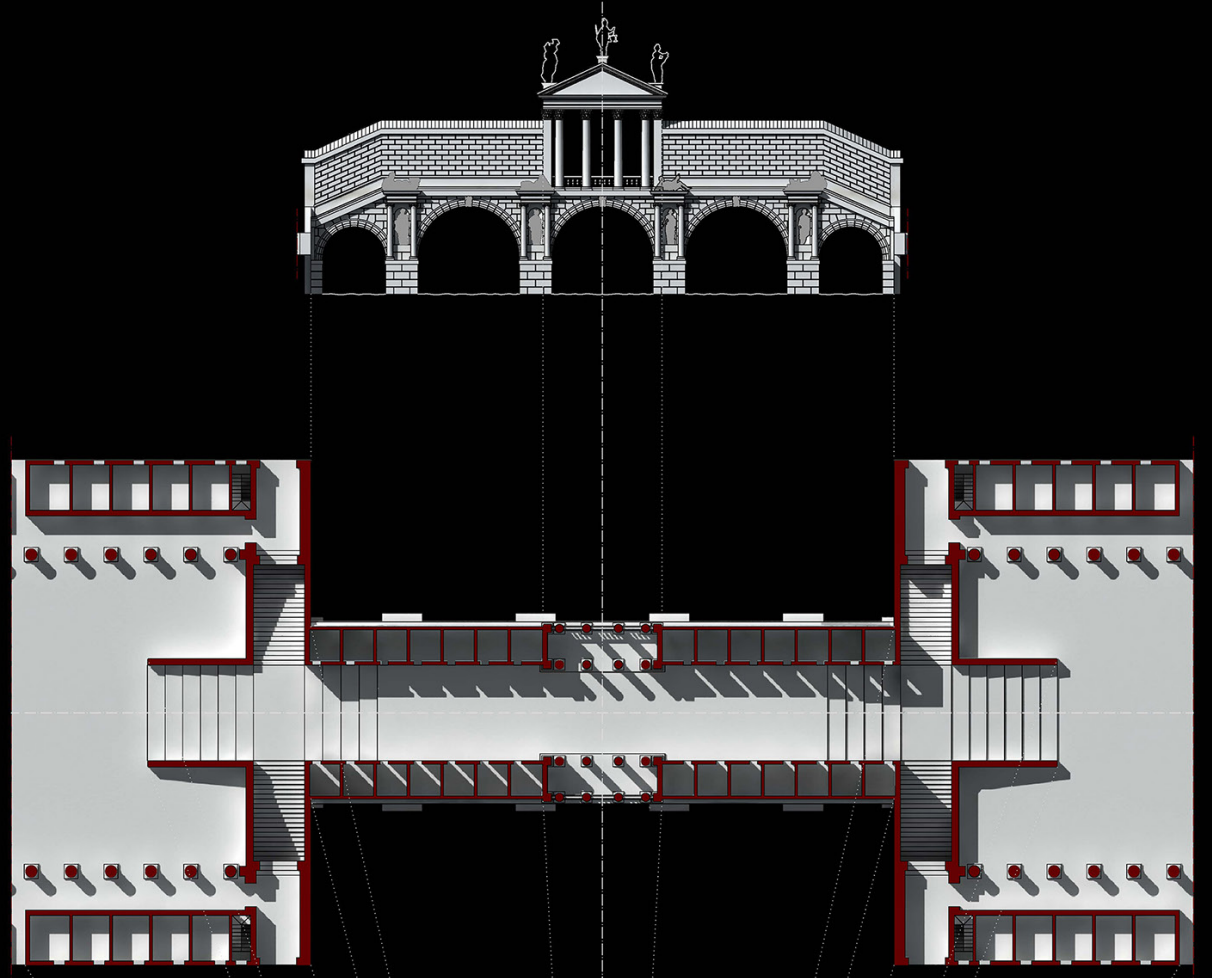

${ }_{0}=-C=-C=0$
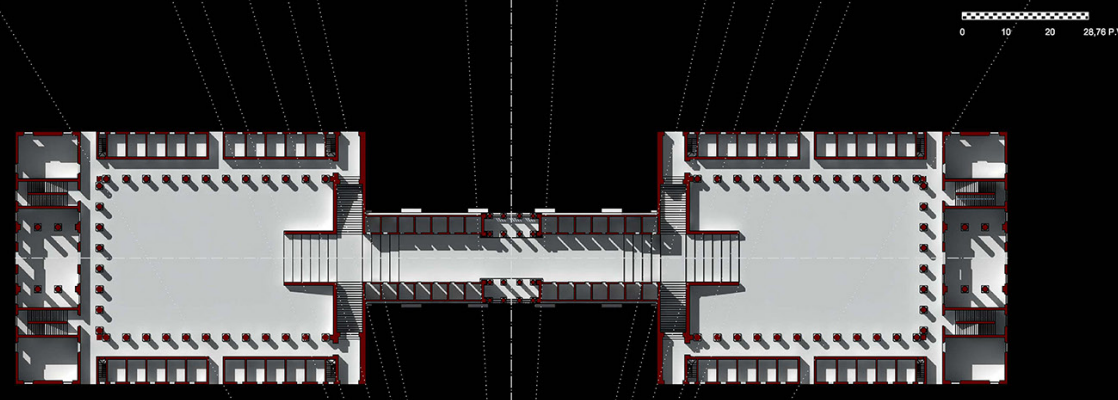

$0-5$

$\begin{array}{lll}0 & 10 \quad 20 & 28,76 \mathrm{P}\end{array}$

Fig. 2. Digital recon-

struction of the first

version of the Palladio

bridge for Rialto (graphic

elaboration by P. Rava- 
Fig. 3. Andrea Palladio, plan and elevation of a bridge (identified with the second version of the Rialto bridge) [Palladio 1570 book III, p. 26]

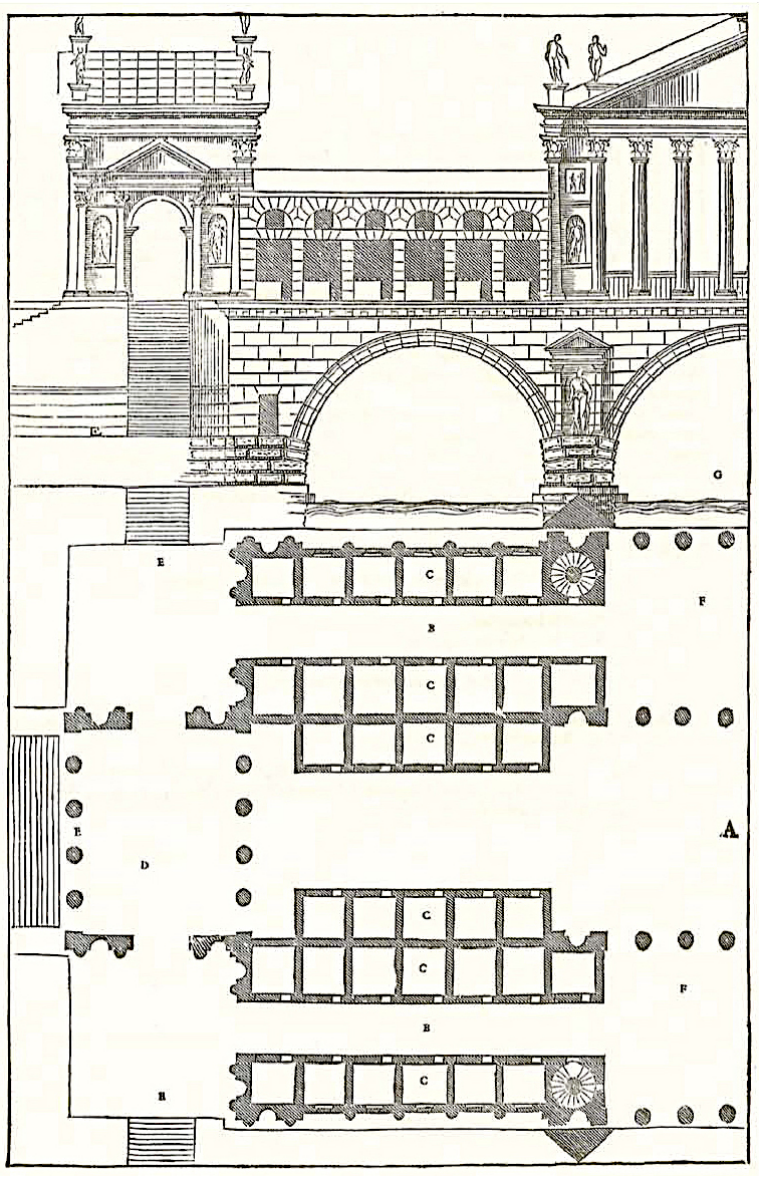

need of the context with an adequate architectural solution, designing "three ways: the wide, beautiful one; and the other two, which were one minor per band" [Palladio I570, III, p. 25]. A real town square, therefore, having a flat configuration, since it was anticipated -at both ends- by two flights of stairs that allow those who crossed to stop comfortably inside. The author adds that in reality his "invention" derives from Roman suggestions, since, as he writes, "the Ponte Elio in Rome [...] was in ancient times still covered entirely with loggias" [Palladio I 570, III, p. 25].

As Donatella Calabi and Paolo Morachiello have also described, the story of the Rialto bridge is quite complex [Calabi, Morachiello 1987]. In fact, it was a question of replacing the wooden bridge that has undergone several renovations - which can still be seen in the volume of Jacopo de' Barbari from the 1500s- with a stone structure. Already in I 554 the bridge supervisors requested alternative proposals and projects, but only in I 569 the Venetian Senate want to build a bridge for that area. The two design hypotheses for Rialto, similar but at the same time very different, can be considered among the most interesting solutions of Palladio's stone bridges. Both versions reflect the main idea of a multifunctional bridge with shops that we have described above, located in the central area of the Venice market. Among the recurring characters in the two versions for the Venetian bridge are the systematic use of arches with a structural value, the architectural orders and the central tympanum which gave a hierarchy to the entire complex.

The first solution for Rialto (ca. I553-1554) (fig. I) can be found in a document kept at the Civic Museum of Vicenza. The drawings show on the recto the partial elevation of the five-arched bridge and on the verso side its planimetric development, of considerable interest as it is one of the few examples of a Palladian urban-scale project that has survived to us [Beltramini 2008]. The structure can be sized thanks to the specific metric indicated in the 
Fig. 4. Digital reconstruction of the econd version of the (graphic elaboration by P. Ravagnan).

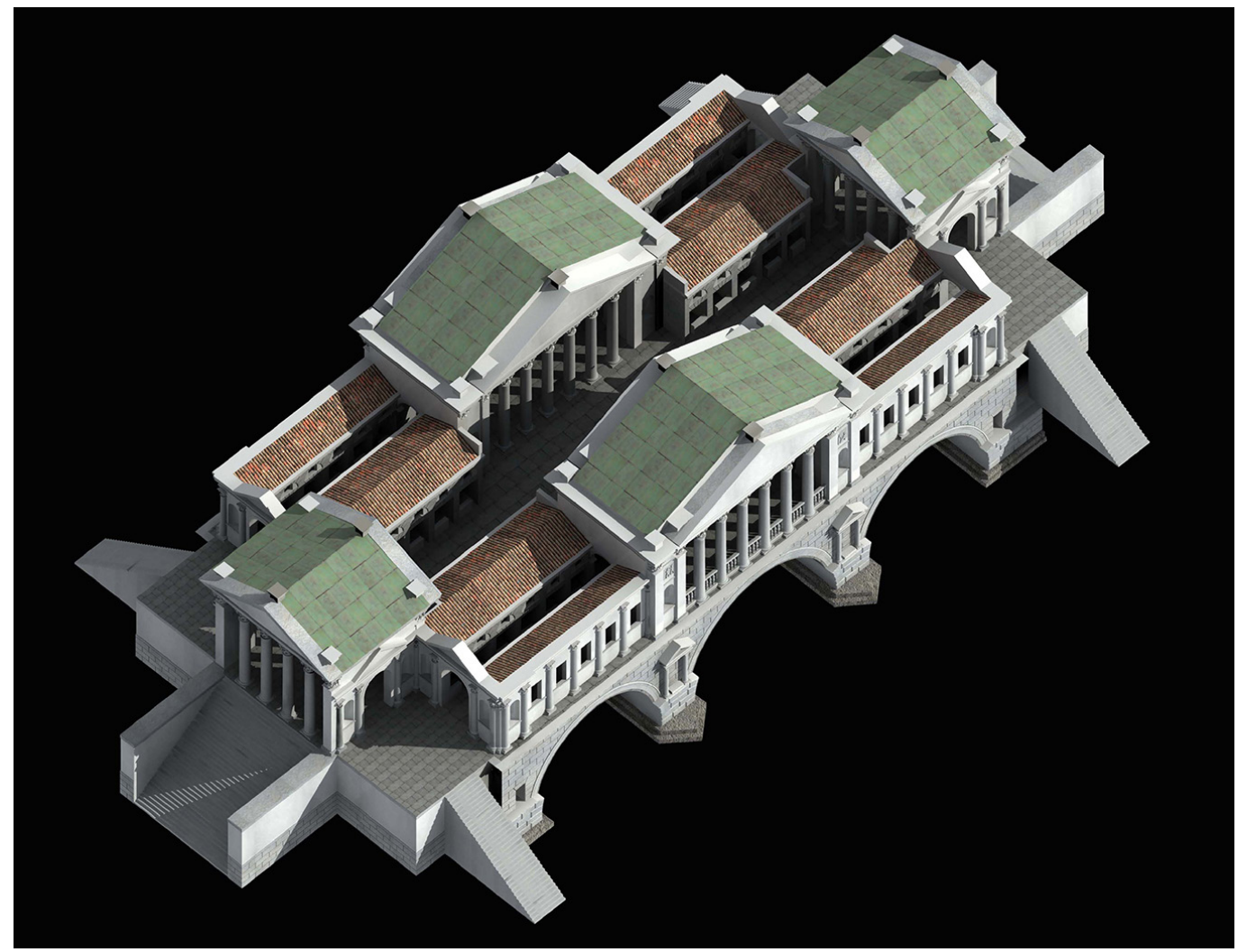

drawing: the bridge is 132 feet $(45.89 \mathrm{~m})$ long, while the two fields at the end of the bridge measure $32 \times 26$ 'pasa' (pasa stands for step, $1.78 \mathrm{~m}$, or 5 Vicenza feet), which correspond to $57.20 \mathrm{~m}$ in length and $46.47 \mathrm{~m}$ in width.

There is no information on the interiors, but we can identified two sets of seven shops on two sides and some stairs.

The modeling of the first version of the Palladian bridge (fig. 2) and of the decoration of its apparatuses was started according to the graphic materials available. The study was also applied to the location of the site, tracing the sides of the river and the water.

The second project for the Rialto Bridge (fig. 3), better known than the first, was published by Palladio in the Quattro Libri. Starting from Palladian graphics, numerous redrawings were made during the eighteenth century, including those by Francesco Muttoni and Ottavio Bertotti Scamozzi. Of particular importance for the development of this research was the essay by Antonio Rondelet [Rondelet I 84 I]: the author, trying to better understand the history of the Palladian bridge, studied its structure and feasibility of construction by providing valuable considerations and details.

In addition to these insights, the digital determination of the bridge (fig. 4) was based on the drawings of the treatise (plan, longitudinal elevation and section of the work), which
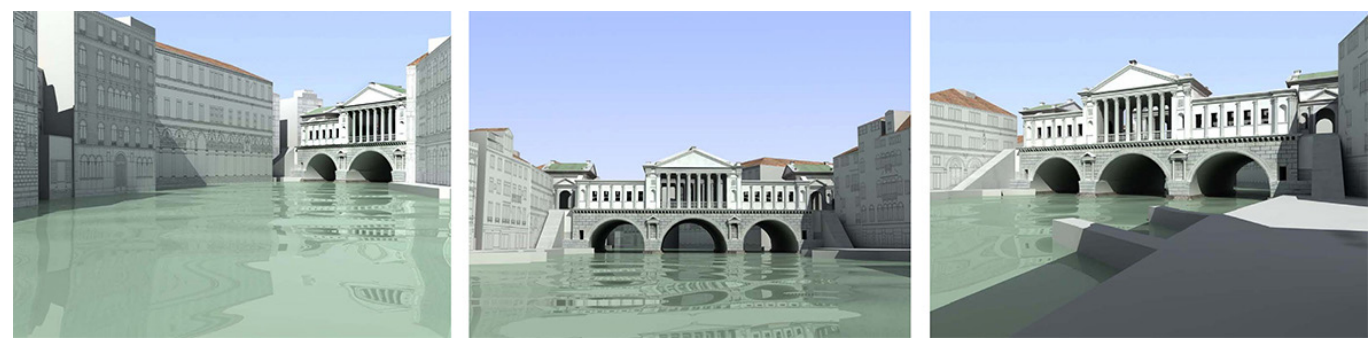

Fig. 5. Frames of the digital video animation of the second version of the Palladio bridge for Rialto area (graphic elaboration by P. Ravagnan). 
constituted a sufficient description of the main parts which were then reconstructed in three dimensions.

Then, we did a digital animation to verify the actual impact that this work would have had if it had been created, adopting a particular figurative stratagem: the verisimilitude of the unrealized bridge was counterbalanced by the virtuality of the real prospects of the Venetian context, applied as textures graphics on the volumes of the buildings, digitally reconstructed, overlooking the Grand Canal (fig. 5). A subtle communicative exercise to relate reality and virtuality in their mutual correspondence.

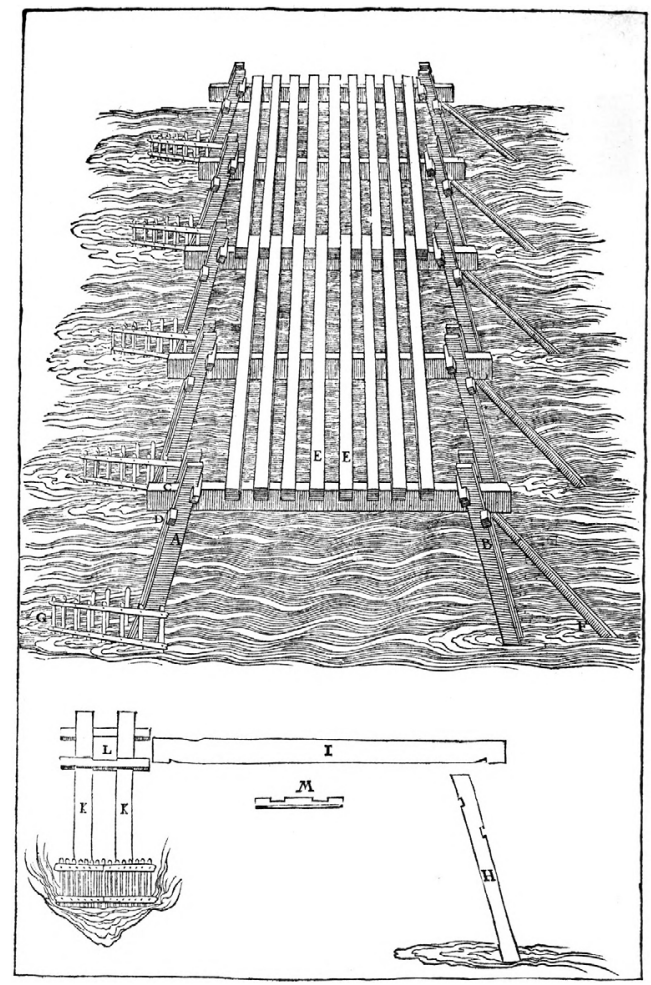

\section{Caesar's bridge over the Rhine}

Among the bridges of the past that most intrigued the architect from Vicenza there is the bridge over the Rhine that Gaius Julius Caesar had built on the Rhine in 55 BC. in a delicate moment of the Gaul war. Connecting the two shores through a temporary structure would have allowed, in addition to the physical overcoming of the river that divided the two territories of the Gauls and the Germans, also to acquire that fame, esteem and notoriety, which would last over time.

Built in just ten days and made entirely of wood on frames arranged in profile with respect to the river current, the bridge met the specific requirements of rapid assembly (thanks to the organization of the construction process, as well as the seriality and prefabrication of the elements) and structural resistance (for the ingenuity of the connections that employed the particular clasps called fibulae), in addition to the Vitruvian ones of firmitas, utilitas, and venustas. Composed of modules arranged in succession, the bridge could be 'infinitely' long, except for the difficulty of having to insert support poles in rivers of excessive depth. Caesar's proposal described in De Bello Gallico leaves ample room for doubt on the technique used, so much so that there have been various hypotheses made over the years, 


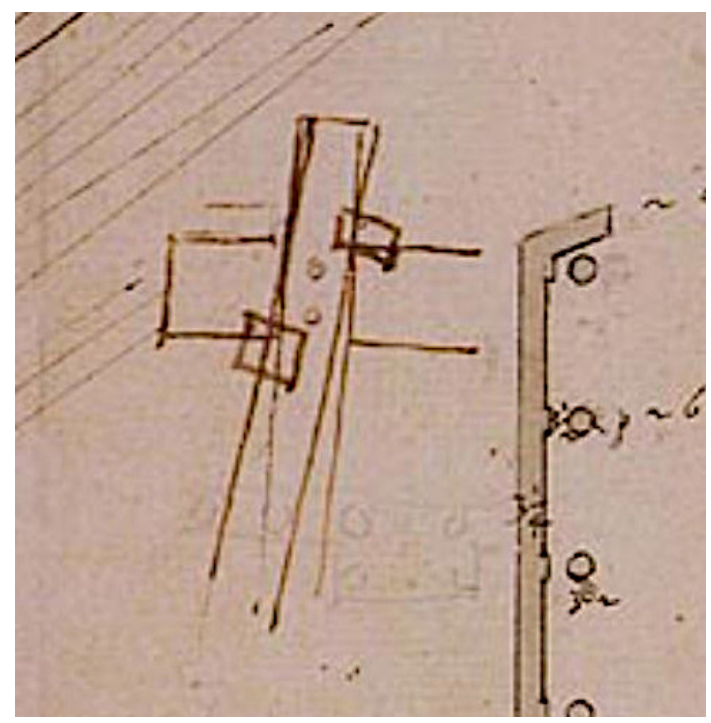

including that of Fra Giocondo, Leon Battista Alberti, Jean Borrel and Andrea Palladio. The Palladian solution seems to be the most interesting, because it manages to solve the fibula's interlocking system -only mentioned by Caesar in his text but not described-avoiding the use of nails.

The research involved the digital construction of the Caesar's bridge based on Palladio's interpretation, physical prototyping for technical verification and dynamic simulation of the impact of water on the bridge with immersive virtual reality techniques.

The reconstruction of the Caesar's bridge over the Rhine, according to the Palladian hypothesis, was conducted through the comparison and analysis of the following sources: the table on page I 4 of book III of the I Quattro Libri dell'Architettura (fig. 6); the sketch of the functioning of the fibulae preserved in the RIBA archive in London (Vol. XI, Fol. I9) [I] (fig. 7); table XIV of the edition of I Commentari di C. Giulio Cesare [Caesar 1575] [2]. To these have been added some studies recently conducted [Scolari 2002; Beltramini 2002].

The architect from Vicenza reported in the treatise what was described in the text of Caesar by adopting the ancient Roman foot [3] $(29.62 \mathrm{~cm})$ as a unit of measurement, precisely dimensioning the transverse beam [4], the inclined pillar and the distance between two inclined pillars [5]. From the Palladian drawings it is possible to deduce the inclination between the transverse beam and the pylons [6], the length and section of the fibula and the position of the notches on the beam and pylons. The upper and lower interlocking teeth are shown mutually in the sketch of the RIBA and in the table of his treatise.

The wheelbase of the trestles is not specified in any way by Palladio, but is attributable by carrying out a geometric restitution on the transverse beams and joists represented in the overall perspective view (fig. 8). The perspective restitution, in fact, made it possible to determine, in addition to the size of the individual beams of the upper frame, also the distance between the transverse beams (about 40 feet) and consequently the overall length of the portion of the bridge represented (4 spans, about 160 feet). The total height of the bridge cannot be deduced from the Quattro Libri's table, except for the length of the inclined pylons represented above the water level (about 16 and a half feet).

Having deduced these graphical and dimensional information, the research continued with the three-dimensional determination of the elements -geometrically simplified according to the Palladian drawing- that make up the bridge, verifying the geometric and structural principles of the solution and continuous reproducibility both in the modeling and prototyping phase growth of this connecting architecture (figs. 9, I0). This procedure has therefore confirmed how the use of modularity and prefabrication allows easy and rapid construction, as well as the disassembly and replacement of parts for any needs. 
Fig. 8. Perspective

restitution of Palladio's

design for the project

for the Caesar bridge

over the Rhine (graphic elaboration by V. Riavis).
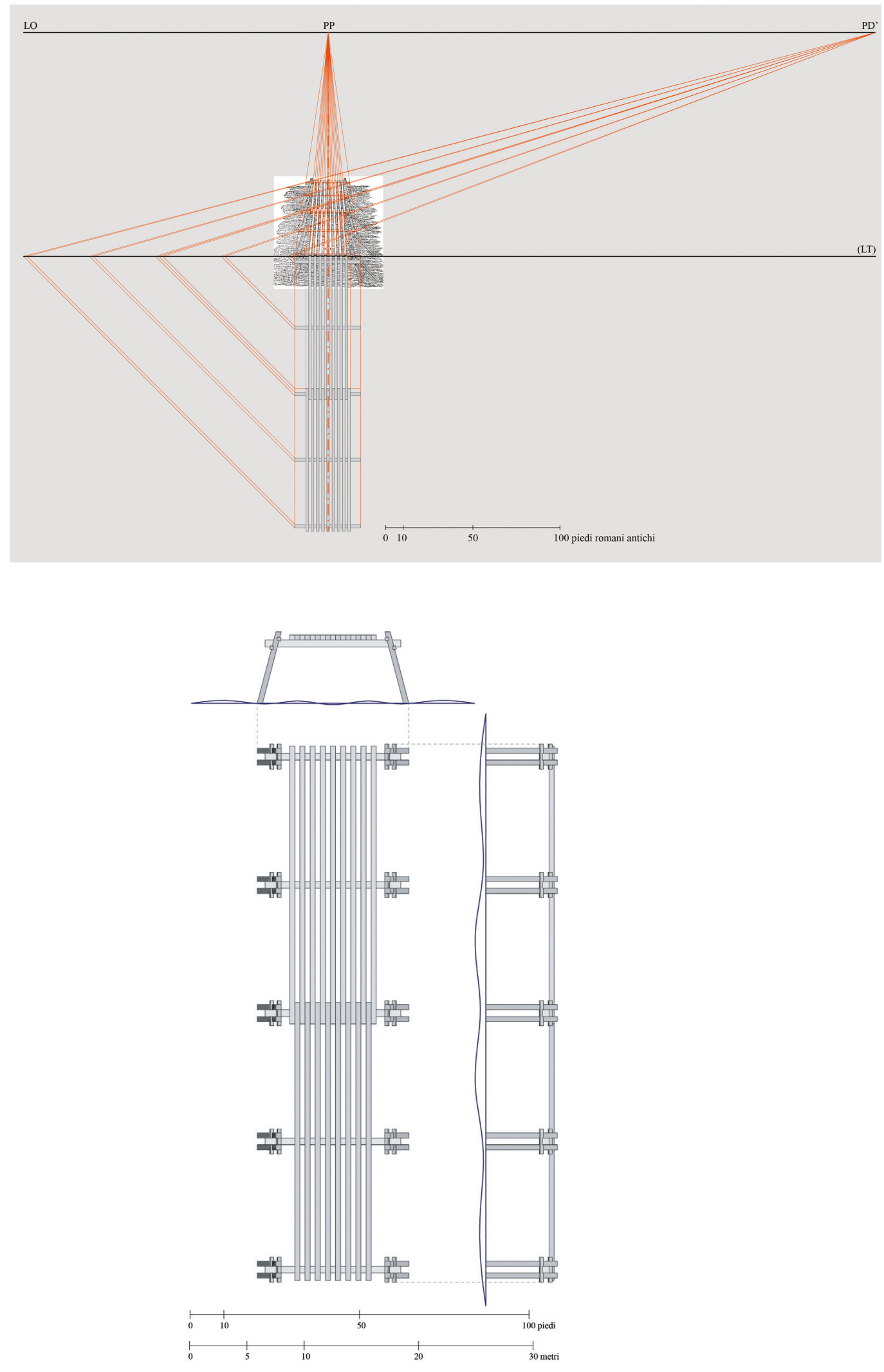

2712
Fig. 9. Plan and elevations of the Caesar bridge over the Rhine, according to

Palladio's interpretation

V. Riavis) 
Fig. 10. Axonometry of the digital model of Palladio's project for the Caesar bridge over the Rhine (graphic elabor tion by V. Riavis).
Fig. I I. Massimo Scolari, sketch of the installation for the Caesar bridge over the Rhine according to Palladio at Palazzo Barbaran da Porto in Vicenza, 2002.

Fig. 12. Installation by Massimo Scolari for the Caesar bridge over the Rhine according Palladio at Palazzo BarbaPalladio at Palazzo Barbaran da Porto in Vicenza. 2002 (photo

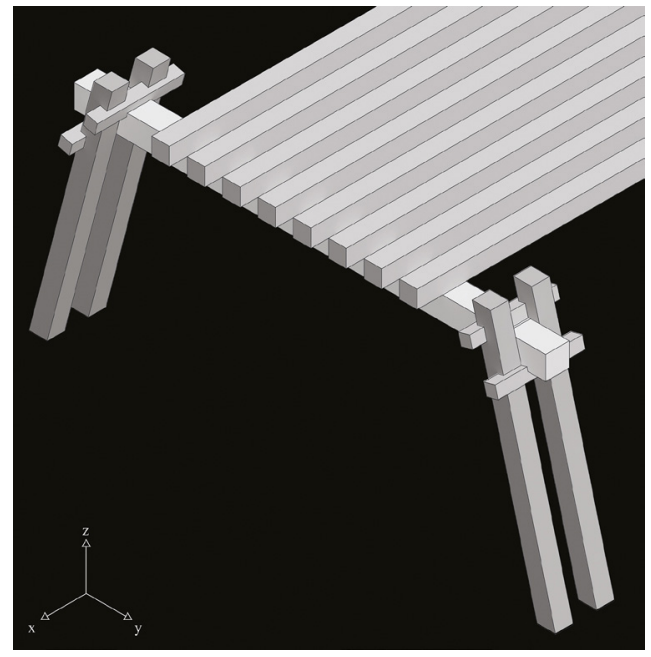

A reconstruction of the coupling system of the beam with the pole was made by Massimo Scolari in 2002 (figs. II, 12) in the occasion of the exhibition John Soane and the Swiss wooden bridges. Architecture and technical culture from Palladio to the Grubenmanns held at Palazzo Barbaran da Porto in Vicenza, where the Centro Internazionale di Studi di Architettura Andrea Palladio is located. On this occasion it was possible to observe in detail the Palladian solution, with the system of fibulae that allowed to support the joint between the vertical structural element and the horizontal beam, also thanks to the fact that Scolari decided to double the scale of the elements, transforming this technical trick in a real architectural sculpture of great perceptual impact and thus restoring that impression of grandeur very present in some works of ancient writers. It is no coincidence that Massimo Scolari reminds us that "for this work, as grandiose as it is ephemeral, the words Plutarch wrote about Demetrius' military works might apply: 'their great proportions also terrified his friends, their beauty he also delighted his enemies' (Plutarch, Life of Demetrius, I 8)" [Scolari 2002, pp. 4, 5].
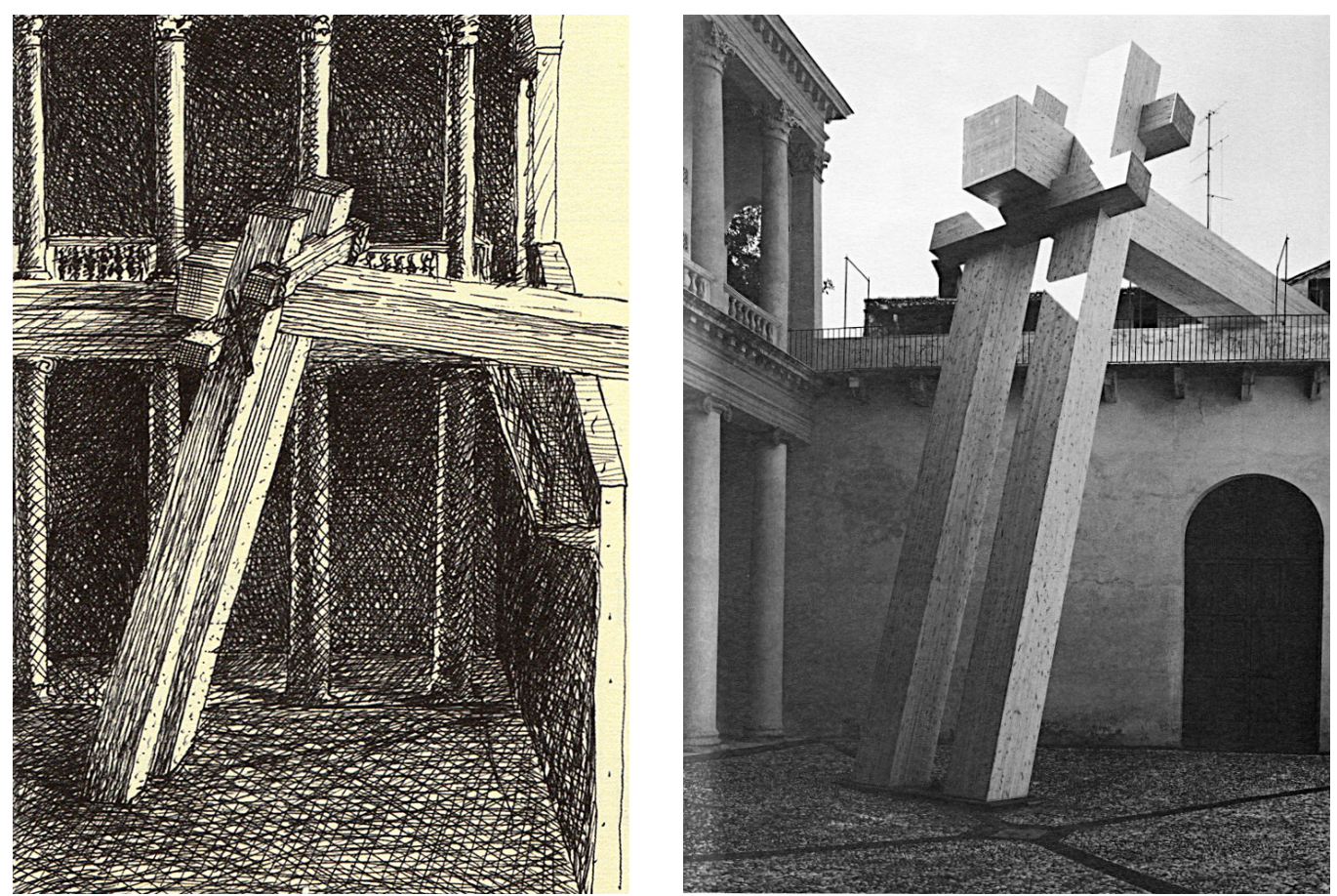


\section{Conclusions}

The issue relating to the design and construction of bridges is among the most interesting in many aspects, including political, social and technical ones. Bridges, in fact, play an important role in the attempt to dominate nature and overcome its obstacles, giving the possibility of acquiring a certain territory even militarily, or of carrying out commercial and cultural exchanges.

The considerable technical difficulties associated with their design and execution mainly concern the construction site dynamics, the characteristics and movement of loads, as well as the defense against waterways (floods and floods) and maintenance.

Based on the graphic and documentary information available both in the Quattro Libri, as well as Palladio's autograph drawings and subsequent studies conducted by various authors on the work of the architect from Vicenza, the research presented here was completed by giving digital form to the bridges analyzed - the two projects for Rialto, and the interpretation of the Caesar Bridge over the Rhine.

The different versions of bridges have been addressed through solid modeling and NURBS for the three-dimensional reconstruction of the compositional elements of different geometric complexity.

All digital models have been optimized and aimed to understand the geometric and functional reconstruction of them, both in the form of dynamic simulation (video and immersive animation) and physical simulation using rapid prototyping techniques. In this way it was possible not only to appreciate the richness of the Palladian architectural detail, but also to verify the functioning of the connective components that make up the bridges he conceived and analyzed.

\section{Notes}

[I]This is a detail of the functioning of the fibula schematically represented alongside the drawings of the Forum of Nerva and the Temple of Minerva [Zorzi 1958, p. 74, fig. I48].

[2] The textual source consists in the translation of the passage of Julius Caesar and in the image captions provided on page 13 of the Quattro Libri, faithfully reported in the edition of the Commentaries.

[3] It has been assumed that Palladio considers this unit of measurement on the basis of some findings made by Howard Burns on the drawings of the antiquities of Verona [Beltramini 2002, p. I6]

[4] The presence of a discontinuity for the length of the transverse beam between what is reported in the caption (40 feet) with respect to the schematic drawing of the tables of the Four Books and the Commentaries (length reduced to 29 feet) is specified.

[5] Transverse beam ( $40 \times 2 \times 2$ feet), inclined pylon $(1.5 \times 1.5$ feet $\times$ indefinite length due to the absence of information on the river bed) and distance between two inclined pylons ( 2 feet).

[6] Inclination between transverse beam and pylons $\left(105^{\circ}\right)$, length and section of the fibula $(7.5 \times|\times|$ feet $)$,

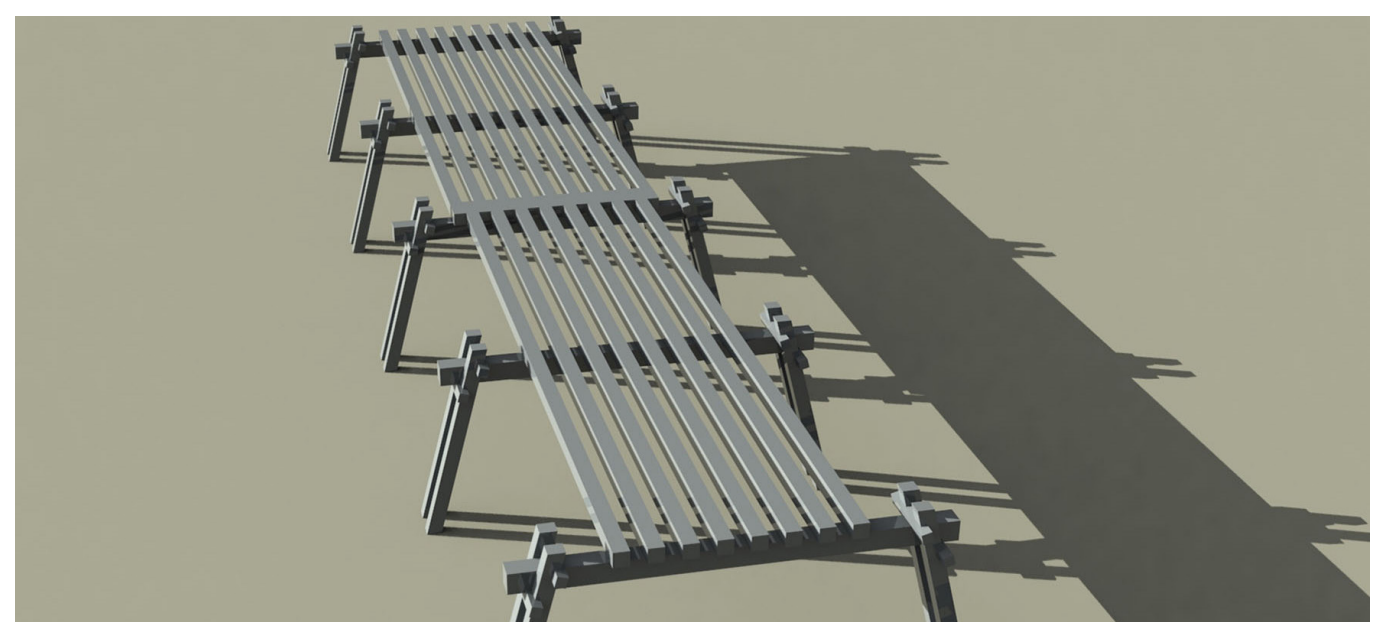




\section{References}

Azzi Visentini Margherita (1980). I ponti di Palladio. Milano: Electa.

Battilotti Donata (2008). Belli, forti e durevoli? I ponti di Palladio. In Barbieri Franco et al. (a cura di). Palladio I508-I580. II simposio del cinquecentenario. Venezia: Marsilio.

Beltramini Guido (2002). Andrea Palladio e il ponte di Cesare. In Scolari Massimo. Il ponte di Cesare sul Reno secondo Palladio. In Quaderni del Museo Palladio, 4. p. 16.

Beltramini Guido (2008).Venezia: i progetti per Rialto. In Beltramini Guido, Burns Howard (a cura di). Palladio.Venezia: Marsilio, pp. 184-195.

Bertotti Scamozzi Ottavio (1796). Le fabbriche e i disegni di Andrea Palladio raccolti e illustrati da Ottavio Bertotti Scamozzi. Vicenza: Giovanni Rossi.

Caesar Gaius lulius (1520). Commentaria Caesaris prius à locundo impressioni data.... Florentiae: per haeredes Philippi luntae.

Caesar Gaius lulius (I575). I Commentari di C. Giulio Cesare, con le figure in rame de gli alloggiamenti, de' fatti d'arme, delle circonuallationi delle citta, \& di molte altre cose notabili descritte in essi. Fatte da Andrea Palladio per facilitare a chi legge, la cognition dell'historia. Venezia: Pietro de Franceschi.

Calabi Donatella, Morachiello Paolo (1987). Rialto: le fabbriche e il ponte, I 5 / 4- I59 I. Torino: Einaudi.

Gros Pierre, Beltramini Guido (2002). Il ponte di Cesare sul Reno. In Maggi Angelo, Navone Nicola (a cura di). John Soane e i ponti in legno svizzeri. Architettura e cultura tecnica da Palladio ai Grubenmann. Mendrisio: Accademia di Architettura; Vicenza: Centro Internazionale di Studi di Architettura Andrea Palladio. pp. I63- 189.

Palladio Andrea (1570). I Quattro Libri dell'architettura di Andrea Palladio. Venezia: Domenico De Franceschi.

Rondelet Antonio ( 84 I). Saggio storico sul ponte di Rialto. Mantova: Negretti.

Scolari Massimo (2002). Il ponte di Cesare sul Reno secondo Palladio. In Quaderni del Museo Palladio, 4. pp. I - 6.

Tampone Gennaro (2000). Sulle caratteristiche strutturali ed esecutive dei ponti lignei di Palladio. Firenze, Bollettino Ingegneri, 12 pp. 2-6

Tampone Gennaro, Mannucci Massimo, Macchioni Nicola (2002). Strutture di legno. Cultura, conservazione, restauro. Milano: De Lettera.

Zorzi Giangiorgio (1958). I disegni delle antichità di Andrea Palladio.Venezia: Neri Pozza Editore.

\footnotetext{
Authors

Alberto Sdegno, Università degli Studi di Udine, alberto.sdegno@uniud.it

Veronica Riavis, Università degli Studi di Udine, veronica.riavis@uniud.it
}

Per citare questo capitolo: Sdegno Alberto, Riavis Veronica (2020). "Una strada fatta sopra dell'acqua”: genesi e rappresentazione di alcuni pont palladiani/"A road made above water": genesis and representation of some palladian bridges. In Arena A., Arena M., Brandolino R.G., Colistra D., Ginex G., Mediati D., Nucifora S., Raffa P. (a cura di). Connettere. Un disegno per annodare e tessere. Atti del $42^{\circ}$ Convegno Internazionale de Docenti delle Discipline della Rappresentazione/Connecting. Drawing for weaving relationships. Proceedings of the 42th International Conference of Representation Disciplines Teachers. Milano: FrancoAngeli, pp. 2694-27I5 